\title{
Dampak Model Pembelajaran Mind Mapping dalam Meningkatkan Hasil Belajar Siswa di Sekolah Dasar
}

\author{
Ni Nyoman Kurnia Wati ${ }^{*}$ \\ ${ }^{1}$ Jurusan Dharma Acarya, STAHN Mpu Kuturan, Singaraja, Indonesia
}

\section{A R T I C L E I N F O}

Article history:

Received July 16, 2021

Revised July 25, 2021

Accepted October 20, 2021

Available online November 25, 2021

Kata Kunci:

Model Mind Mapping, Hasil Belajar

Keywords:

Mind Mapping Model, Learning Outcomes

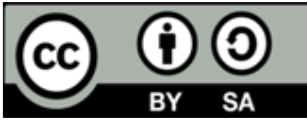

This is an open access article under the CC BY-SA license.

Copyright $(2021$ by Author. Published by Universitas Pendidikan Ganesha.

\begin{abstract}
A B S T R A K
Penyusunan pembelajaran yang kurang menarik bagi siswa, sehingga siswa cepat bosan dan kurang aktif dalam pembelajaran. Hal ini mengakibatkan hasil belajar siswa menjadi rendah. Tujuan penelitian ini adalah untuk menganalisis besarnya pengaruh model pembelajaran mind mapping dalam meningkatkan hasil belajar siswa sekolah dasar secara keseluruhan dan besar pengaruh model pembelajaran mind mapping dalam meningkatkan hasil belajar siswa sekolah dasar berdasarkan mata pelajaran. Metode yang digunakan dalam penelitian ini adalah metode metaanalisis. Penelitian ini dilakukan dengan menganalisis kepustakaan terhadap penelitianpenelitian eksperimen yang dihasilkan pada sekolah dasar. Penelitian metaanalisis ini menggunakan analisis data deskriptif kuantitatif. Analisis ini digunakan untuk menganalisis data perhitungan besar pengaruh (effect size) yang diperoleh dari membandingkan hasil mean dan standar deviasi penelitian sebelumnya. Berdasarkan kajian pustaka dan hasil analisis pada penelitian ini dapat disimpulkan bahwa model pembelajaran mind mapping dalam meningkatkan hasil belajar siswa di sekolah dasar dapat dilakukan pada beberapa mata pelajaran, memiliki kategori sedang, layak, dan mendukung untuk dilakukan pada pembelajaran, khususnya di SD. Implikasi penelitian ini, guru dapat menerapkan model pembelajaran mind mapping pada proses pembelajaran untuk meningkatkan hasil belajar siswa.
\end{abstract}

\begin{abstract}
A B S T R A C T
Less interesting learning arrangements for students so that students do not get bored quickly and are active in learning. This causes student learning outcomes are still low. The purpose of this study was to analyze the magnitude of the influence of the mind mapping learning model in improving the overall learning outcomes of elementary school students and the magnitude of the influence of the mind mapping learning model in improving the learning outcomes of elementary school students based on subjects. The method used in this research is the meta-analysis method. This research was conducted by analyzing the literature on experimental studies produced in elementary schools. This meta-analysis research uses quantitative descriptive data analysis. This analysis is used to analyze the effect size data obtained from comparing the results of the mean and standard deviation of previous studies. Based on the literature review and the results of the analysis in the research that took the title of mind mapping learning model in improving student learning outcomes in elementary schools, it can be concluded that the mind mapping learning model in improving student learning outcomes in elementary schools can be carried out on several subjects, has a moderate category, decent and support to be carried out in learning, especially in elementary school. The implication of this research is that teachers can apply mind mapping learning models in the learning process to improve student learning outcomes.
\end{abstract}

\section{PENDAHULUAN}

Pendidikan juga berarti suatu proses pengubahan sikap dan tingkah laku seseorang atau sekelompok orang dalam mendewasakan melalui pembelajaran dan latihan (Aruan et al., 2017; Saputro \& Murdiono, 2020). Pendidikan memiliki tujuan untuk menciptakan seseorang yang berkualitas dan berkarakter, sehingga memiliki pandangan yang luas ke depan untuk mencapai suatu cita- cita yang di 
harapkan dan mampu beradaptasi secara cepat dan tepat di dalam berbagai lingkungan (Nasr et al., 2018; Prasanti \& Fitrianti, 2018). Pendidikan memotivasi diri manusia untuk lebih baik dalam segala aspek kehidupan (Monika \& Adman, 2017). Pendidikan memiliki peran yang penting dalam membentuk dan menciptakan peserta didik yang berkarakter dan berkualitas (Pitaloka et al., 2021; Surya, 2017). Pendidikan menjadi harapan bangsa dalam mencetak generasi unggul yang cerdas dan bertanggung jawab terhadap negaranya. Satu yang menjadi harapan pendidikan adalah pengajar yang mumpuni atau dengan kata lain pengajar yang professional. Upaya tersebut dilakukan dengan meningkatkan kualifikasi dan persyaratan jenjang pendidikan yang lebih tinggi bagi tenaga pengajar mulai tingkat prasekolah sampai perguruan tinggi (Patabang \& Murniarti, 2021; Simanjuntak, 2020).

Masalah dalam pembelajaran yang dirasakan guru di antaranya perilaku siswa yang beragam, konsentrasi siswa kurang, pengajaran yang kurang kreatif, kurang interaksi dalam pelajaran (Kurnia \& Dwikurnaningsih, 2019; Zairmi et al., 2019). Permasalahan yang kerap terjadi adalah masih rendahnya hasil belajar pada mata pelajaran tertentu utamanya di sekolah dasar (Hendriana, 2018; Kasanah et al., 2019). Hasil wawancara juga menyatakan bahwa salah satu masalah yang dihadapi guru adalah menyusun pembelajaran yang kurang menarik bagi siswa, sehingga siswa tidak bosan dan kurang aktif dalam pembelajaran. Hal ini mengakibatkan hasil belajar siswa masih rendah. Hasil belajar yang diharapkan orang tua, guru, dan pemerintah adalah hasil belajar yang baik dalam setiap pembelajaran yang dicapai siswa. Namun, tentunya tidak semua yang diharapkan dapat terwujud dengan lancar. Banyak kendala yang dihadapi guru dalam meningkatkan hasil belajar siswa. Salah satu kendalanya, siswa belum mampu mengoptimalkan kinerja otak dengan membuat catatan-catatan kecil dan memetakan informasi dalam pikirannya. Hal ini perlu dibantu dengan suatu model pembelajaran.

Model pembelajaran adalah suatu perencanaan atau suatu pola yang digunakan sebagai pedoman dalam melaksanakan pembelajaran di kelas atau pembelajaran dalam tutorial (Lutfi et al., 2017; Metha Rozhana \& Harnanik, 2019). Model pembelajaran yang ideal adalah model yang mengekspolarasi pengalaman belajar efektif, yaitu pengalaman belajar yang memungkinkan siswa mengalami atau berbuat secara langsung dan aktif dalam sebuah lingkungan belajarnya (Berliana et al., 2018; Misla \& Mawardi, 2020). Fungsi model pembelajaran adalah pedoman dalam perancangan hingga pelaksanaan pembelajaran. Oleh karena itu, pemilihan model sangat dipengaruhi oleh sifat dari materi yang akan dibelajarkan, tujuan (kompetensi) yang akan dicapai dalam pembelajaran tersebut, serta tingkat kemampuan peserta didik. Model pembelajaran yang dapat mendukung tercapainya hasil belajar yang diharapkan guru adalah model pembelajaran mind mapping (Arsana et al., 2019; Nurroeni, 2013; Wu \& Chen, 2018). Model pembelajaran mind mapping merupakan sebuah model yang menitikberatkan pada pengoptimalan kerja otak, yaitu otak bagian kiri dan bagian kanan digunakan secara bersamaan, sehingga pembentukan pengetahuan bekerja secara menyeluruh dan bermakna (Ekawati \& Kusumaningrum, 2020; Kusuma, 2014; Maria et al., 2021). Model ini memetakan segala yang dipikirkan dan dibuat secara visual, sehingga akan memudahkan seseorang untuk menguraikan atau mengutarakan apa yang ada dalam pikirannya sesuai dengan peta pikiran yang dibuat (Putri, 2018; Ruhama \& Erwin, 2021). Peta pikiran memungkinkan individu merekam informasi melalui simbol, gambar, arti emosional, dan warna (Polat \& Aydın, 2020; Putra et al., 2017). Mekanisme ini sama persis dengan cara otak memproses berbagai informasi yang masuk karena peta pikiran melibatkan kedua belah otak. Dengan demikain. siswa dapat mengingat informasi dengan lebih mudah.

Banyak hasil penelitian tentang model pembelajaran mind mapping dilakukan oleh dosen maupun mahasiswa. Penerapan model pembelajaran mind mapping ini juga dilakukan pada berbagai variabel seperti motivasi, minat belajar, prestasi belajar, kemampuan berpikir kritis, hasil belajar dan variabel lainnya (Maria et al., 2021). Mind mapping berpengaruh pada keterampilan menulis ringkasan siswa, kususnya dalam pembelajaran bahasa Indonesia (Saharah \& Indihadi, 2019). Hal ini menyebabkan perlu adanya suatu analisis kepustakaan tentang model pembelajaran mind mapping, sehingga diketahui besar effect size dari penelitian-penelitian tersebut. Tujuan penelitian ini adalah untuk mengetahui besarnya pengaruh model pembelajaran mind mapping dalam meningkatkan hasil belajar siswa sekolah dasar secara keseluruhan dan besar pengaruh model pembelajaran mind mapping dalam meningkatkan hasil belajar siswa sekolah dasar berdasarkan mata pelajaran.

\section{METODE}

Metode yang digunakan dalam penelitian ini adalah metode metaanalisis. Metaanalisis adalah teknik statistika untuk menggabungkan hasil penelitian yang jumlahnya dua (2) atau lebih, memiliki kesamaan variabel atau sejenis, sehingga diperoleh paduan data secara kuantitatif. Metaanalisis merupakan analisis kuantitatif dan menggunakan sejumlah data yang cukup banyak serta menerapkan metode statistik dengan mempraktikkannya dalam mengorganisasikan sejumlah informasi yang berasal 
dari sampel besar yang fungsinya untuk melengkapi maksud-maksud lainnya. Metanalisis juga berarti mencari effect size dari penelitian-penelitian yang ada. Syarat melakukan metaanalisis adalah pengkajian terhadap hasil-hasil penelitian yang sejenis atau memiliki variabel yang sama, baik itu variabel bebas maupun variabel terikatnya.

Penelitian ini dilakukan dengan menganalisis kepustakaan terhadap penelitian-penelitian eksperimen yang dihasilkan pada sekolah dasar. Penelitian di sekolah dasar yang dianalisis adalah penelitian yang meneliti tentang hasil belajar siswa dengan menggunakan model atau metode mind mapping. Dalam setiap penelitian tentunya mengkaji beberapa variabel. Variabel merupakan suatu konsep yang penting dalam penelitian. Variabel yang umum dalam sebuah penelitian adalah variabel bebas (Independent Variable) dan variabel terikat (Dependent Variable). Varibel bebas adalah variabel yang memengaruhi atau menjadi sebab perubahan atau timbulnya variabel terikat (Sugiyono, 2013), yang menjadi variabel bebas dalam penelitian ini adalah model pembelajaran mind mapping. Variabel terikat merupakan variabel yang dipengaruhi atau yang menjadi akibat karena adanya variabel bebas. Variabel terikat dalam penelitian ini adalah hasil belajar siswa sekolah dasar. Pada pelaksanaan penelitian ini karena terbatasnya kemampuan dan waktu, maka penelitian ini memiliki keterbatasan penelitian. Peneliian yang digunakan adalah penelitian yang menggunakan model pembelajaran mind mapping. Efektivitas yang dicari adalah efektivitas mata pelajaran dan pengaruhnya terhadap hasil belajar siswa sekolah dasar.

Penelitian metaanalisis ini merupakan penelitian yang menggunakan data sekunder berupa datadata dari hasil penelitian sebelumnya. Dengan demikian, penelitian ini menggunakan teknik pengumpulan data berbentuk analisis kepustakaan terhadap penelitian-penelitian yang telah dilakukan sebelumnya. Penelitian metaanalisis ini menggunakan analisis data deskriptif kuantitatif. Analisis data deskriptif adalah analisis statistik yang digunakan untuk menggambarkan atau menganalisis suatu hasil penelitian, tetapi tidak digunakan untuk generalisasi/inferensi (Koyan, 2012). Statistik deskriptif berkaitan dengan kegiatan pencatatan, penyusunan, penyajian dan peringkasan dengan mendeskripsikan atau menggambarkan data-data yang hasil-hasil pengamatan terhadap kejadian-kejadian atau fenomenafenomena. Analisis deskriptif kuantitatif adalah suatu cara pengolahan data yang dilakukan dengan jalan menyusun secara sistematis dalam bentuk angka-angka dan atau presentase, mengenai suatu objek yang diteliti, sehingga diperoleh kesimpulan umum (Agung, 2014). Analisis ini digunakan untuk menganalisis data perhitungan besar pengaruh (effect size) yang diperoleh dari membandingkan hasil mean dan standar deviasi penelitian sebelumnya.

\section{HASIL DAN PEMBAHASAN}

Hasil

Banyak hasil penelitian yang sudah mengkaji tentang model pembelajaran Mind Mapping, namun tidak banyak yang mengkaji efect size dari model pembelajaran Mind Mapping. Oleh sebab itu, dilakukan metaanalisis untuk mengkaji besarnya pengaruh Model Pembelajaran mind mapping dalam meningkatkan hasil belajar siswa sekolah dasar secara keseluruhan, besar pengaruh model pembelajaran mind mapping dalam meningkatkan hasil belajar siswa sekolah dasar berdasarkan mata pelajaran, dan seberapa besar pengaruh (effect size) model pembelajaran mind mapping dalam meningkatkan hasil belajar siswa sekolah dasar. Pada tahap awal peneliti akan memilih beberapa jenis penelitian baik itu penelitian eksperimen yang menggunakan model pembelajaran Mind Mapping yang mencari pengaruhnya terhadap hasil belajar siswa sekolah dasar. Data penelitian yang menggunakan model pembelajaran mind mapping terhadap hasil belajar siswa pada Tabel 1 .

Tabel 101. Efect Size secara keseluruhan

\begin{tabular}{|c|c|c|c|c|c|c|c|c|c|}
\hline \multirow[t]{2}{*}{ No } & \multirow[t]{2}{*}{ Kode Penelitian } & \multicolumn{2}{|c|}{$n$} & \multicolumn{2}{|c|}{$M$} & \multicolumn{2}{|c|}{ SD } & \multirow[t]{2}{*}{$d$} & \multirow[t]{2}{*}{ Kategor } \\
\hline & & $\mathbf{E}$ & $\mathbf{K}$ & $\mathbf{E}$ & $\mathbf{K}$ & $\mathbf{E}$ & $\mathbf{K}$ & & \\
\hline 1 & A1 & 32 & 32 & 84 & 78 & 10,2 & 9,6 & 0,6 & Sedang \\
\hline 2 & S1 & 31 & 30 & 86 & 70 & 11,5 & 10,2 & 0,7 & Sedang \\
\hline 3 & $\mathrm{~T} 1$ & 20 & 21 & 87 & 77 & 5,5 & 2,6 & 0,5 & Sedang \\
\hline 4 & $\mathrm{~T} 2$ & 27 & 28 & 81 & 62 & 6,3 & 3,29 & 0,8 & Tinggi \\
\hline 5 & $\mathrm{I} 1$ & 33 & 33 & 79 & 72 & 9,6 & 5,7 & 0,8 & Tinggi \\
\hline \multicolumn{6}{|c|}{ Rata-rata $d$} & & & 0,68 & Sedang \\
\hline
\end{tabular}

Dari hasil analisis yang tercantum pada Tabel 01 diketahui bahwa besaran pengaruh model pembelajaran mind mapping dalam meningkatkan hasil belajar di sekolah dasar secara keseluruhan 
adalah 0,68. Nilai ini termasuk dalam kategori sedang. Dari keseluruhan 5 unit analisis penelitian, terdapat 3 unit analisis penelitian yang berada pada nilai besaran pengaruh secara keseluruhan sedang dan 2 unit analisis penelitian yang berada pada besaran pengaruh tinggi. Penelitian pengaruh menggunakan model pembelajaran mind mapping dalam meningkatkan hasil belajar siswa di sekolah dasar dilakukan pada beberapa mata pelajaran seperti IPA, PKN, IPS, dan Tematik. Untuk itu, dicari besarnya effect size pada penelitian yang menggunakan model pembelajaran mind mapping dalam meningkatkan hasil belajar siswa di sekolah dasar berdasarkan mata pelajarannya. Data effect size penelitian yang menggunakan model pembelajaran mind mapping dalam meningkatkan hasil belajar siswa di sekolah dasar berdasarkan mata pelajarannya Tabel 2.

Tabel 02. Efect Size berdasarkan Matapelajaran

\begin{tabular}{cccc}
\hline No & Mata Pelajaran & $\boldsymbol{d}$ & Kategori \\
\hline 1 & IPA & 0,6 & Sedang \\
2 & IPS & 0,7 & Sedang \\
3 & Tematik & 0,65 & Sedang \\
4 & Indonesia & 0,8 & Tinggi \\
\hline & Rata-rata $\boldsymbol{d}$ & $\mathbf{0 , 6 8}$ & Sedang \\
\hline
\end{tabular}

Dari hasil analisis besaran pengaruh model pembelajaran mind mapping dalam meningkatkan hasil belajar siswa di sekolah dasar berdasarkan mata pelajaran pada tabel 02 diketaui bahwa besaran pengaruh model pembelajaran mind mapping dalam meningkatkan hasil belajar siswa di sekolah dasar adalah 0,68 dengan kategori sedang. Besaran pengaruh model pembelajaran mind mapping dalam meningkatkan hasil belajar siswa di sekolah dasar pada mata pelajaran IPA adalah 0,6 dengan kategori sedang, besaran pengaruh model pembelajaran mind mapping dalam meningkatkan hasil belajar siswa di sekolah dasar mata pelajaran tematik adalah 0,65 dengan kategori tinggi, dan besaran pengaruh model pembelajaran mind mapping dalam meningkatkan hasil belajar siswa di sekolah dasar mata pelajaran IPS adalah 0,7 dengan kategori sedang, dan besaran pengaruh model pembelajaran mind mapping dalam meningkatkan hasil belajar siswa di sekolah dasar mata pelajaran Bahasa Indonesia adalah 0,8 dengan kategori tinggi.

\section{Pembahasan}

Belajar dan mengajar merupakan dua konsep yang tidak bisa dipisahkan satu sama lainnya . Belajar merujuk pada sesuatu yang harus dilakukan seseorang sebagai subjek dalam belajar, sedangkan mengajar merujuk pada sesuatu yang seharusnya dilakukan seseorang guru sebagai pengajar. Dua konsep belajar dan mengajar yang dilakukan oleh siswa dan guru terpadu dalam satu kegiatan yang disebut proses pembelajaran. Hasil belajar merupakan hasil yang diperoleh oleh siswa dalam bentuk kemampuan, keterampilan, dan sikap setelah melakukan kegiatan belajar. Hasil belajar yang diperoleh oleh siswa dapat diamati dan dapat diukur melalui kegiatan penilaian. Penilaian dapat diartikan sebagai sutu tindakan atau kegiatan untuk menilai sejauh mana tujuan-tujuan intruksional dapat tercapai dan sejauh mana materi yang diberikan dikuasai siswa (Nisa et al., 2018; Prayito, 2011). Pentingnya hasil belajar menjadi suatu hal yang harus selalu diperhatikan oleh pendidik. Banyak faktor yang mempengaruhi keberhasilan siswa dalam menangkap materi pembelajaran, baik faktor internal maupun eksternal (Purwantoko, Susilo, 2010). Keanekaragaman sifat dan karakter menjadikan setiap siswa memiliki cara yang berbeda dalam belajar. Banyak model, strategi, metode pembelajaran yang dilakukan untuk meningkatkan hasil belajar siswa sekolah dasar. Salah satu yang menjadi bahasan dalam penelitian ini adalah model pembelajaran mind mapping.

Mind mapping adalah cara mencatat yang kreatif, efektif, dan secara harfiah akan memetakan pikiran-pikiran. Mind Mapping merupakan proses memetakan pikiran untuk menghubungkan konsep tertentu yang dituangkan kedalam suatu tulisan yang menarik dan kreatif menyerupai peta kota. Dengan demikian, konsep pembelajaran tersebut akan mudah dipahami oleh otak. Model pembelajaran mind mapping merupakan suatu model pembelajaran yang mengaktifkan kedua bagian otak dalam pembelajaran (Boerma et al., 2021; Ruhama \& Erwin, 2021; Wu \& Chen, 2018). Penggunaan mind mapping dalam proses pembelajaran akan dapat membantu siswa untuk menyusun sebuah ide atau gagasan (Nurroeni, 2013). Melalui mind mapping, siswa akan dapat mengetahui pola berpikir yang sistematis dan terstruktur (Maria et al., 2021). Untuk membuat peta pikiran, guru bisa menggunakan bolpoint berwarna dan memulai dari bagian tengah kertas. Kalau bisa, guru menggunakan kertas secara melebar untuk mendapatkan lebih banyak tempat. Tujuan membuat peta pikiran saat belajar adalah untuk mempermudah mengingat sesuatu dan membantu mencatat informasi penting dengan menggunakan kata 
kunci. Hal ini diharapkan dapat membantu siswa dalam mengingat dan memahami pelajaran, sehingga hasil belajar yang rendah dapat ditingkatkan.

Temuan ini diperkuat dengan temuan sebelumnya yang menyatakan pembelajaran Mind Mapping lebih efektif karena dapat meningkatkan rasa percaya diri terhadap kemampuan berbicara siswa (Maria et al., 2021). Mind mapping dapat meningkatkan minat dan hasil belajar keterampilan berbicara (Darmuki, 2020). Metode mind map berbasis drill dapat meningkatkan keaktifan dan hasil belajar kemampuan berbicara mahasiswa (Hidayati, 2020). Strategi mind mapping pada peserta didik secara signifikan mampu meningkatkan prestasi belajar peserta didik (Fanita, 2021). Terdapat perbedaan hasil belajar siswa antara sebelum dan sesudah perlakuan metode mind mapping pada kelompok eksperimen Dari beberapa penelitian sebelumnya menunjukkan mind mapping efektif diterapkan pada proses pembelajaran (Umam \& Ahyani, 2017). Penerapan model pembelajaran mind mapping memberikan pengaruh terhadap hasil belajar (Ekawati \& Kusumaningrum, 2020; Ruhama \& Erwin, 2021). Berdasarkan kajian pustaka dan hasil analisis pada model pembelajaran mind mapping dalam meningkatkan hasil belajar siswa di sekolah dasar. Secara keseluruhan, model pembelajaran mind mapping dalam meningkatkan hasil belajar siswa di sekolah dasar memiliki nilai besaran pengaruh yang termasuk dalam kategori sedang dan besaran pengaruh model pembelajaran mind mapping dalam meningkatkan hasil belajar siswa di sekolah dasar berdasarkan mata pelajaran memiliki nilai besaran pengaruh yang termasuk dalam kategori sedang.

\section{SIMPULAN}

Model pembelajaran mind mapping dalam meningkatkan hasil belajar siswa di sekolah dasar dapat dilakukan pada beberapa mata pelajaran. Pengujian besaran pengaruh model pembelajaran mind mapping dalam meningkatkan hasil belajar siswa di sekolah dasar memiliki kategori sedang, layak, dan mendukung untuk dilakukan pada pembelajaran, khususnya di SD. Pendidik yang belum pernah melaksanakan model pembelajaran mind mapping dapat mencobanya dalam pembelajaran di sekolah dasar.

\section{DAFTAR RUJUKAN}

Agung, A. A. G. (2014). Metodologi Penelitian Pendidikan. Aditya Media Publishing.

Arsana, I. K., Suarjana, M., \& Arini, N. W. (2019). Pengaruh Penggunaan Mind Mapping Berbantuan Alat Peraga Tangga Garis Bilangan terhadap Hasil Belajar Matematika. International Journal of Elementary Education, 3(2), 99-107. https://doi.org/10.23887/ijee.v3i2.18511.

Aruan, R., Sujana, E., Luh, N., \& Erni, G. (2017). The Influence of Taxpayer Attitudes, Taxpayer Morals and Willingness to Pay Individual Taxes at the Tax Office (KPP) Pratama Gianyar. E-Journal S1 Ak Universitas Pendidikan Ganesha, 8(2), 1-10.

Berliana, N., Enawati, E., \& Lestari, I. (2018). Pengaruh Penggunaan Media Chemcrossworld Puzzle terhadap Motivasi dan Hasil Belajar Siswa SMP. Jurnal Pendidikan Dan Pembelajaran Khatulistiwa, 7(9), 2. https://jurnal.untan.ac.id/index.php/jpdpb/article/view/27820/75676578050.

Boerma, I., van der Wilt, F., Bouwer, R., van der Schoot, M., \& van der Veen, C. (2021). Mind Mapping during Interactive Book Reading in Early Childhood Classrooms: Does It Support Young Children's Language Competence? Early Education and Development, 1-17. https://doi.org/10.1080/10409289.2021.1929686.

Darmuki, A.-. (2020). Peningkatan Minat Dan Hasil Belajar Keterampilan Berbicara Menggunakan Metode Mind Map pada Mahasiswa Kelas IA PBSI IKIP PGRI Bojonegoro Tahun Akademik 2019/2020. KREDO: Jurnal Ilmiah Bahasa Dan Sastra, 3(2), 263-276. https://doi.org/10.24176/kredo.v3i2.4687.

Ekawati, N. M., \& Kusumaningrum, D. (2020). Pengaruh Penerapan Metode Pembelajaran Mind Mapping terhadap Hasil Belajar Siswa Kelas V Sekolah Dasar Negeri 2 Sumberrejo Tahun Pelajaran 2018/2019. JPDI Jurnal Pendidikan Dasar Indonesia), 5(2), 31. https://doi.org/10.26737/jpdi.v5i2.2091.

Fanita, I. (2021). Meningkatkan Kemampuan Menulis Siswa dengan Menggunakan Mind Mapping pada Pembelajaran Bahasa Inggris Kelas XI . IPS . 1 SMAN Sungai Lala. Jurnal Pendidikan Tambusai, 5(3), 5911-5916.

Hendriana, E. C. (2018). Pengaruh Model Pembelajaran Problem Based Learning dan Gaya Belajar Auditorial terhadap Hasil Belajar IPS di Sekolah Dasar. Jurnal Pendiidikan Dasar Indonesia, 3(1), 1 - 8. https://doi.org/10.26737/jpdi.v3i1.484.

Hidayati, N. A. (2020). Penerapan Metode Mind Map Berbasis Drill untuk Meningkatkan Kemampuan 
Berbicara Mahasiswa di Prodi PBSI IKIP PGRI Bojonegoro. Jurnal Educatio FKIP UNMA, 6(2), 462468. https://doi.org/10.31949/educatio.v6i2.578.

Kasanah, S. A., Damayani, A. T., \& Rofian, R. (2019). Keefektifan Model Pembelajaran Role Playing Berbantu Media Multiply Cards terhadap Hasil Belajar Siswa. Jurnal Ilmiah Sekolah Dasar, 3(4), 529. https://doi.org/10.23887/jisd.v3i4.22308.

Koyan, I. W. (2012). Statistik Pendidikan Teknik Analisis Data Kuantitatif. Universitas Pendidikan Ganesha.

Kurnia, H. S., \& Dwikurnaningsih, Y. (2019). Penerapan Model TTW Berbasis Saintifik untuk Meningkatkan Hasil Belajar Tema Kebersamaan pada Siswa Kelas II SDN Kutowinangun 11. Jurnal Basicedu, 3(1), 250 - 256. https://doi.org/10.31004/basicedu.v3i1.113.

Kusuma, S. P. (2014). Pengaruh Metode Pembelajaran dan Berpikir Kreatif terhadap Hasil Belajar Sejarah Siswa SMA. Jurnal Pendidikan Sejarah, 3(2), 28. https://doi.org/10.21009/jps.032.04.

Lutfi, Ismail, \& Azis, A. A. (2017). Pengaruh Project Based Learning Terintegrasi STEM terhadap Literasi Sains, Kreativitas, dan Hasil Belajar Peserta Didik. Prosiding Seminar Nasional Biologi Dan Pembelajarannya, 189-194.

Maria, Y., Kara, D. K., \& Liru, M. W. (2021). Pengaruh Strategi Pembelajaran Mind Mapping dan Rasa Percaya Diri terhadap Kemampuan Berbicara Bahasa Inggris. Edukatif: Jurnal Ilmu Pendidikan, 3(6), 4980-4986. https://doi.org/https://doi.org/10.31004/edukatif.v3i6.1600.

Metha Rozhana, K., \& Harnanik, H. (2019). Lesson Study dengan Metode Discovery Learning dan Problem Based Instruction. Inteligensi: Jurnal Ilmu Pendidikan, 1(2), 39-45. https://doi.org/10.33366/ilg.v1i2.1355.

Misla, M., \& Mawardi, M. (2020). Efektifitas PBL dan Problem Solving Siswa SD Ditinjau dari Kemampuan Berpikir Kritis. Jurnal Ilmiah Sekolah Dasar, 4(1), 60. https://doi.org/10.23887/jisd.v4i1.24279.

Monika, M., \& Adman, A. (2017). Peran Efikasi Diri dan Motivasi Belajar dalam Meningkatkan Hasil Belajar Siswa Sekolah Menengah Kejuruan. Jurnal Pendidikan Manajemen Perkantoran, 2(2), 219-226. https://doi.org/10.17509/jpm.v2i2.8111.

Nasr, M., Bagheri, M. S., Sadighi, F., \& Rassaei, E. (2018). Iranian EFL Teachers' Perceptions of Assessment for Learning Regarding Monitoring and Scaffolding Practices as A Function of Their Demographics. Cogent Education, 5(1), 1-29. https://doi.org/10.1080/2331186X.2018.1558916.

Nisa, N. A. K., Widyastuti, R., \& Hamid, A. (2018). Pengembangan Instrumen Assesment Higher Order Thinking Skill (HOTS) pada Lembar Kerja Peserta Didik Kelas VII SMP. Prosiding Seminar Nasional Matematika Dan Pendidikan Matematika, 3(3), 543-556.

Nurroeni, C. (2013). Keefektifan Penggunaan Model Mind Mapping terhadap Aktivitas dan Hasil Belajar. $\begin{array}{llll}\text { Journal Of Elementary 54-60. } & \text { 2(1), }\end{array}$ https://journal.unnes.ac.id/sju/index.php/jee/article/view/2081.

Patabang, A., \& Murniarti, E. (2021). Analisis Kompetensi Pedagogik Guru pada Pembelajaran Daring di Masa Pandemi Covid-19. Edukatif: Jurnal Ilmu Pendidikan, 3(4), 1418-1427. https://doi.org/10.31004/edukatif.v3i4.584.

Pitaloka, D. L., Dimyati, D., \& Edi, P. (2021). Peran Guru dalam Menanamkan Nilai Toleransi pada Anak Usia Dini di Indonesia. Jurnal Obsesi: Jurnal Pendidikan Anak Usia Dini, 5(2), 1696-1705. https://doi.org/10.31004/obsesi.v5i2.972.

Polat, Ö., \& Aydın, E. (2020). The Effect of Mind Mapping on Young Children's Critical Thinking Skills. Thinking Skills and Creativity, 38. https://doi.org/10.1016/j.tsc.2020.100743.

Prasanti, D., \& Fitrianti, D. R. (2018). Pembentukan Karakter Anak Usia Dini: Keluarga, Sekolah, dan Komunitas. Jurnal Obsesi: Jurnal Pendidikan Anak Usia Dini, 2(1), 13-19. https://doi.org/10.31004/obsesi.v2i1.2.

Prayito. (2011). Pengembangan Perangkat Pembelajaran Matematika Humanistik Berbasis Konstruktivisme Berbantuan E-Learning Materi Segitiga Kelas VII. AKSIOMA Journal of Mathematics Education, 2(2). https://doi.org/10.26877/aks.v2i2/Septembe.37.

Purwantoko, Susilo, S. (2010). Kefektifan Pembelajaran dengan Menggunakan Media Puzzle terhadap Pemahaman IPA. Jurnal Pendidikan Fisika Indonesia, 6, 124. https://journal.unnes.ac.id/nju/index.php/JPFI/article/viewFile/1124/1043.

Putra, I. K. D. A. S., Margunayasa, I. G., \& Wibawa, I. M. C. (2017). Pengaruh Model Pembelajaran Inkuiri Terbimbing Berbantuan Peta Pikiran terhadap Hasil Belajar IPA Kelas V SD. Jurnal Pendidikan, 5(2), 1-10. https://doi.org/10.23887/jjpgsd.v5i2.10711.

Putri, A. C. D. (2018). Pengaruh Model Mind Mapping terhadap Hasil Belajar Siswa pada Materi Peristiwa Sekitar Proklamasi Kemerdekaan. PEDADIDAKTIKA: Jurnal Ilmiah Pendidikan Guru Sekolah Dasar, 5(1), 118-126.

Ruhama, I. A., \& Erwin, E. (2021). Pengaruh Penerapan Model Pembelajaran Mind Mapping terhadap Hasil Belajar IPA Siswa Sekolah Dasar di Masa Pandemi Covid-19. Jurnal Basicedu, 5(5), 3841-3849. 
https://doi.org/10.31004/basicedu.v5i5.1422.

Saharah, S., \& Indihadi, D. (2019). Penggunaan Teknik Mind Mapping pada Keterampilan Menulis Ringkasan Siswa dalam Pembelajaran Bahasa Indonesia. Jurnal Ilmiah Pendidikan Guru Sekolah Dasar, 6(1), 9-15.

Saputro, J. D., \& Murdiono, M. (2020). Implementation of Character Education through a Holistic Approach to Senior High School Students. International Journal of Multicultural and Multireligious Understanding, 7(11), 460-470. https://doi.org/10.18415/ijmmu.v7i11.2146.

Simanjuntak, R. (2020). Memaknai Profesionalisme Guru Pendidikan Agama Kristen Masa Kini. Sanctum Domine: Jurnal Teologi, 9(1), 27-44. https://doi.org/10.46495/sdjt.v9i1.56.

Sugiyono. (n.d.). Metode Penelitian Kuantitatif Kualitatif. Alfabeta.

Sugiyono. (2013). Metode Penelitian Pendidikan Pendekatan Kuantitatif, Kualitatif, dan R\&D. Alfabeta.

Surya, Y. F. (2017). Penggunaan Model Pembelajaran Pendidikan Karakter Abad 21 pada Anak Usia Dini. Jurnal Obsesi: Jurnal Pendidikan Anak Usia Dini, 1(1), 52-61. https://doi.org/10.31004/obsesi.v1i1.30.

Umam, D. S., \& Ahyani, L. N. (2017). Pengaruh Penerapan Metode Mind Mapping terhadap Hasil Belajar Bahasa Indonesia Siswa SD Kelas 3. Jurnal Psikologi Perseptual, 1(2), 70-83. https://doi.org/10.24176/perseptual.v1i2.1637.

Wu, T.-T., \& Chen, A.-C. (2018). Combining E-Books with Mind Mapping in A Reciprocal Teaching Strategy for A Classical Chinese Course. Computers \& Education, 116. https://doi.org/10.1016/j.compedu.2017.08.012.

Zairmi, U., Fitria, Y., \& Amini, R. (2019). Penggunaan Model Pembelajaran Two Stay Two Stray dalam Pembelajaran IPA di Sekolah Dasar. Jurnal Basicedu, 3(4), 1031-1037. https://doi.org/10.31004/basicedu.v3i4.221. 